\title{
Role of WNT/ $\beta$-Catenin Signaling in Rejuvenating Myogenic Differentiation of Aged Mesenchymal Stem Cells from Cardiac Patients
}

\author{
Keith R. Brunt, ${ }^{*}$ Yuemei Zhang, ${ }^{*}$ Anton Mihic, ${ }^{*}$ \\ Mingxi Li, ${ }^{\dagger}$ Shu-Hong Li, ${ }^{*}$ Phil Xue, ${ }^{\dagger}$ \\ William Zhang, ${ }^{\dagger}$ Samir Basmaji, ${ }^{\dagger}$ \\ Katherine Tsang, ${ }^{\star}{ }^{\dagger}$ Richard D. Weisel, ${ }^{* \dagger}$ \\ Terrence M. Yau, ${ }^{* \dagger}$ and Ren-Ke Li ${ }^{*}$ \\ From the Division of Cardiovascular Surgery and Toronto \\ General Research Institute, University Health Network, and the \\ Department of Surgery, Division of Cardiac Surgery,* University \\ of Toronto, Toronto, Ontario; and Peter Munk Cardiac Centre, ${ }^{\dagger}$ \\ Toronto General Hospital, University Health Network, Toronto, \\ Ontario, Canada
}

Autologous stem cell therapy has not been as effective as forecasted from preclinical studies. Patient age was reported as an important contributing factor. The goal of this study was to uncover age-dependent mechanisms of stem cell dysfunction and to investigate possible means to restore the cellular function. Bone marrow mesenchymal stem cells (MSCs) were isolated from cardiovascular patients. Cell proliferation and number of colonies were inversely correlated with patient age. Myogenic differentiation of MSCs in culture was induced with 5-azacytidine. Differentiation correlated with age, with less differentiation in MSCs from aged patients. We performed realtime PCR to identify genes in the WNT/ $\beta$-catenin signaling network and found that transcript levels of CTNNB1, LEF1, FZD8, WNT3A, and SFRP4 were negatively correlated with age, whereas FOSL1, LRP6, and FZD6 were positively correlated with age. Protein evaluation showed that $\beta$-catenin nuclear translocation correlated with age and was lower in aged MSCs. Aged MSCs treated with lithium chloride-to increase the bioavailability of $\beta$-catenin-recovered their capacity for myogenic differentiation through myocyte enhancer factor $2 \mathrm{C}$ but not with the knockdown of $\beta$-catenin using small-interfering RNA. This study may be the first to relate reduced nuclear $\beta$-catenin bioavailability in MSCs from aged patients. Most important, this abnormality was potentially recoverable, providing a target for improving the function of bone marrow stem cells and their clinical utility in aged patients. (Am J Patbol 2012, 181:2067-2078; http://dx.doi. org/10.1016/j.ajpath.2012.08.021)

Aging increases the risk of morbidity and mortality in patients with cardiac disease and is associated with stem cell dysfunction and decreased tissue repair after injury. ${ }^{1,2}$ Cell therapy provides a promising opportunity to improve cardiac function after injury, but age limits stem cell function. The results of the initial clinical trials were not as promising as predicted from the preclinical studies, perhaps because the patients were older and had multiple comorbidities. ${ }^{3}$ Recent studies suggest that age was a major factor limiting the benefit of progenitor cellmediated recovery after myocardial injury, although the mechanisms are still unclear. ${ }^{4,5}$ To improve the results of stem cell therapy in elderly patients, attempts should be made to improve cell function. Determining the mechanisms responsible for stem cell dysfunction and identifying ways to rejuvenate aged stem cells could renew the promise of cell therapy to improve the recovery of aged patients.

Human bone marrow stem cells are readily isolated during cardiac procedures and show beneficial effects when used for myocardial repair. ${ }^{3}$ Although the mechanism is not fully understood, the evidence showed that stem cell therapy improves the recovery of ventricular function primarily by the release of paracrine factors. Recently, predifferentiation of human bone marrow mul-

Funded by a grant from the Canadian Institutes of Health Research (MOP102535 to R.-K.L.). K.R.B. is a Heart and Stroke Foundation of Canada Research Fellow. A.M. is funded as a Canadian Institutes of Health Research doctoral candidate.

Accepted for publication August 16, 2012.

Supplemental material for this article can be found at http://ajp. amjpathol.org or at http://dx.doi.org/10.1016/j.ajpath.2012.08.021.

Address reprint requests to Terrence Yau, M.D., Division of Cardiovascular Surgery, University Health Network, Toronto, ON M5G 1L7, Canada; or Ren-Ke Li, M.D., Ph.D., MaRS Centre, Toronto Medical Discovery Tower, 101 College St., Room 3-702, Toronto, ON M5G 1L7, Canada. E-mail: terry.yau@uhn.on.ca or renkeli@uhnresearch.ca. 
tipotent mesenchymal stem cells (MSCs) to a myogenic phenotype was shown to enhance their therapeutic effectiveness in a murine model. ${ }^{6}$

The WNT/ $\beta$-catenin signaling network is closely linked to stem cell self-renewal and differentiation through regulation of CTNNB1, ${ }^{7}$ the gene encoding $\beta$-catenin, and, most important, it plays an essential role in myogenic and cardiogenic development. ${ }^{8}$ Cytosolic $\beta$-catenin is available for nuclear translocation in the presence of WNT activity. ${ }^{9}$ After translocation to the nucleus, $\beta$-catenin interacts with TCF/LEF transcription factors to regulate genes associated with self-renewal, proliferation, and differentiation. In the developing embryo, many of these signals have been well characterized. ${ }^{10}$ Although this system has been implicated in aged phenotypes, ${ }^{11}$ to date, few studies have linked aberrant WNT/ $\beta$-catenin signaling in bone marrow MSCs from cardiac patients with the impaired regenerative potential of the cells.

The objective of this study was to better understand the role of WNT/ $\beta$-catenin signaling in patients with cardiovascular disease to identify new targets for the recovery of stem cell function to improve their utility for cardiac repair. Herein, we determined that the function of MSCs harvested from patients undergoing cardiac surgery correlated with genes involved in the WNT/ $\beta$-catenin signaling network. Increasing age was associated with reduced MSC proliferation, MSC differentiation, and WNT/ $\beta$-catenin signaling. Finally, we demonstrated that some functions of MSCs from aged individuals could be restored with lithium therapy, which increases $\beta$-catenin bioavailability to improve MSC myogenic differentiation.

\section{Materials and Methods}

\section{Human Bone Marrow Samples and Patient Characterization}

Human bone marrow was obtained from patients undergoing cardiovascular surgery at Toronto General Hospital, Toronto, Canada. All the procedures were approved by the Research Ethics Board (REB\#CCR001), and patients provided written informed consent. The 22 study patients were divided into a young group (aged 47, 51, $54,57,57,57,59,60$, and 63 years; mean \pm SD age, $56.1 \pm 4.8$ years) and an aged group (aged 64, 64, 66, $68,70,70,74,74,76,79,79,84$, and 85 years; mean \pm SD age, $73.3 \pm 7.1$ years). These groupings resulted from an attempt to categorize the patients by decade-oflife quartiles: 40 to 50 years, 51 to 60 years, 61 to 70 years, and $>70$ years. Among the individuals in the lower two quartiles, the mean age was 55 years, and 2 SDs (8 years) set the upper level of the young group at 63 years. The aged group ranged from 64 to 85 years, and the 95\% Cls of the two groups differed by 10 years (the upper limit was 59 years for the young group, and the lower limit was 69 years for the aged group).

In addition to age, the cardiovascular risk factors of each patient were documented (Table 1). Cardiac function was graded using the New York Heart Association functional classification and by measuring left ventricular
Table 1. Characteristics of 22 Cardiovascular Patient Stem Cell Donors

\begin{tabular}{|c|c|c|c|}
\hline Characteristic & $\begin{array}{l}\text { Young } \\
\text { group } \\
(n=9)\end{array}$ & $\begin{array}{c}\text { Aged } \\
\text { group } \\
(n=13)\end{array}$ & $P$ value \\
\hline $\begin{array}{l}\text { Age [years, } \\
\quad(\text { mean } \pm \text { SD)] }\end{array}$ & $56.1 \pm 4.8$ & $73.3 \pm 7.1$ & $<0.0001$ \\
\hline Sex, M/F (No.) & $7 / 2$ & $11 / 2$ & \\
\hline $\begin{array}{l}\text { Coronary artery } \\
\text { disease }\end{array}$ & $44(4)$ & $69(9)$ & \\
\hline Valve disease & $55(5)$ & $38(5)$ & \\
\hline $\begin{array}{l}\text { CABG + valve } \\
\text { disease }\end{array}$ & $11(1)$ & $12(1)$ & \\
\hline $\begin{array}{l}\text { Peripheral vascular } \\
\text { disease }\end{array}$ & 0 & $31(4)$ & \\
\hline Smoking & $55(5)$ & $54(7)$ & \\
\hline Diabetes mellitus & $11(1)$ & $15(2)$ & \\
\hline Cholesterolemia & $78(7)$ & $77(10)$ & \\
\hline $\begin{array}{l}\text { Poor LV function } \\
\quad(<40 \% \text { EF })\end{array}$ & 0 & & \\
\hline Statin & $55(5)$ & $85(11)$ & \\
\hline Transfusions & $55(5)$ & $62(8)$ & \\
\hline
\end{tabular}

Values are given as percentage (number) except where otherwise indicated.

$F$, female; $M$, male; $C A B G$, coronary artery bypass graft; EF, ejection fraction; LV, left ventricular.

ejection fraction. The difference in risk factors between age groups was evaluated statistically as described later herein.

\section{Cell Isolation, Culture, and Characterization}

Bone marrow mononuclear cells were isolated by density gradient separation using the Accuspin Histopaque system (Sigma-Aldrich, St. Louis, MO). To evaluate the number of stem cells in the bone marrow cells from young and aged patients, colony-forming unit (CFU) assessment was performed. Freshly isolated bone marrow cells $(2 \times$ $10^{4}$ per dish) were mixed with $1 \mathrm{~mL}$ of MethoCult media (STEMCELL Technologies Inc., Vancouver, BC, Canada) and were cultured in $35-\mathrm{mm}^{2}$ dishes at $37^{\circ} \mathrm{C}, 5 \% \mathrm{CO}_{2}$, and $\geq 95 \%$ humidity. After 7 days, colonies were quantified in a blinded manner using a Nikon Ti-S microscope (Nikon Instruments, Melville, NY).

To characterize the cultured MSCs, cells $\left(1 \times 10^{7}\right)$ were seeded in $175-\mathrm{mm}^{2}$ plates, grown to $80 \%$ confluence, and subcultured to passage 2 before the experimental studies. We randomly selected six MSC samples from patients in each age group and labeled them with antibodies against CD44, CD73, CD90, CD105, CD34, CD45, and CD133 for fluorescence-activated cell sorting analysis.

\section{MSC Growth and Differentiation}

The cells $\left(5 \times 10^{4}\right.$ per dish) were seeded and cultured, and cell growth characteristics were evaluated by growth curves. The number of the cells was determined on day 1 and every 3 days until day 21 after culture by counting using a hemacytometer and trypan blue exclusion. The growth rate was calculated from the linear phase of the growth curve based on cell number over time using trip- 
licate cell counts on days $1,3,7$, and 9 to determine the slope of the line.

For differentiation analysis, MSCs were seeded in 96well suspension cell plates $\left(1.5 \times 10^{4}\right.$ per well). After 1 day of culture, cell clusters from 24 wells were transferred to one $35-\mathrm{mm}^{2}$ dish and were treated with $10 \mu \mathrm{m}$ of 5-azacytidine (5-Aza) for 24 hours. Cells were harvested 18 days later for myosin heavy chain $(\alpha / \beta \mathrm{MHC})$ gene and protein expression analysis using Western blot analysis and quantitative PCR ( $\mathrm{PPCR}$ ).

\section{Cell Viability Assays}

MSCs $\left(8 \times 10^{3}\right)$ were plated in 96-well plates. After 24 hours, cells were treated with $0.3,0.6,0.9$, or $1.2 \mathrm{mmol} / \mathrm{L}$ $\mathrm{H}_{2} \mathrm{O}_{2}$ for 16 hours in triplicate. To evaluate the effect of lithium on viability, cells were treated with $20 \mathrm{mmol} / \mathrm{L}$ lithium chloride for 16 and 72 hours. For the MTT assay (Roche Applied Science, Indianapolis, IN), the media was removed and MTT was added to a final concentration of $1.0 \mathrm{mg} / \mathrm{mL}$, incubated for 4 hours, and solubilized in dimethyl sulfoxide for 24 hours at $37^{\circ} \mathrm{C}$. Absorbance was read at $570 \mathrm{~nm}$, with a reference wavelength of 650 $\mathrm{nm}$. The CyQUANT assay (Invitrogen, Carlsbad, CA), a nonenzymatic assay, measures the total nucleic acid content of cells in culture. Briefly, adherent cells are washed with PBS, dry aspirated, and frozen at $-80^{\circ} \mathrm{C}$. Cells were thawed and lysed in the presence of a nucleic acid-sensitive fluorescent reagent. Relative cell density determination was made using a fluorescent plate reader at an excitation of $480 \mathrm{~nm}$ and emission of $520 \mathrm{~nm}$. For the lactate dehydrogenase (LDH) assay (Roche Applied Science), media from the $\mathrm{H}_{2} \mathrm{O}_{2}$-treated or lithium-treated cells were analyzed for $\mathrm{LDH}$, which is released from dying cells. The determination of LDH activity was performed with a spectrophotometric assay at 490-nm absorbance, based on the oxidation of lactate to pyruvate in the presence of $\mathrm{NADH}$ and a diaphorase catalyst to reduce tetrazolium salt.

\section{Oxidative Stress Analysis}

MSCs $\left(5 \times 10^{5}\right)$ were plated in 6-well plates. After 24 hours, they were treated with $20 \mathrm{mmol} / \mathrm{L}$ lithium chloride for 16 hours. The cell-permeable redox probe CM$\mathrm{H}_{2}$ DCFDA was then added to the media and preloaded at a concentration of $5 \mu \mathrm{mol} / \mathrm{L}$ for 1 hour. The superoxidesensitive probe dihydroethidium was then added for an additional 1 hour. The cells were detached and immediately analyzed by fluorescence-activated cell sorting.

\section{Effect of Lithium on Myogenic Differentiation of Aged Cells}

MSCs were seeded in 96-well suspension cell plates $\left(1.5 \times 10^{4}\right.$ per well). After 1 day of culture, cell clusters from 24 wells were transferred to one $35-\mathrm{mm}^{2}$ dish. After culture of cell clusters for 24 hours, cells were treated as follows: on day 1, $20 \mathrm{mmol} / \mathrm{L}$ lithium chloride; on day 2, 10 $\mu \mathrm{m}$ of $5-A z a$ and $20 \mathrm{mmol} / \mathrm{L}$ lithium chloride; and on day
3, $20 \mathrm{mmol} / \mathrm{L}$ lithium chloride. Cells were harvested on days 7,10 , and 18 after the last treatment for $\alpha / \beta \mathrm{MHC}$ gene and protein expression analysis using Western blot analysis and qPCR.

For transcript knockdown, cells were pretreated with Stealth RNAi against $\beta$-catenin (Invitrogen; sense-5'CCCUCAGAUGGUGUCUGCCAUUGUA-3'; antisense-5'UACAAUGGCAGACACCAUCUGAGGG-3'). Knockdown efficiency was $>70 \%$ and was sustained over the 3-day treatment period. The cells were harvested for cell differentiation analysis.

The interaction between $\beta$-catenin and myocyte enhancer factor $2 \mathrm{C}$ (MEF2C) proteins was predicated using gene modeling interaction software (GeneMANIA prediction server, http://genemania.org, last accessed December 8,2011$).{ }^{12}$

\section{RNA Extraction and $q P C R$}

Total RNA from differentiated MSCs was extracted using the RNeasy mini kit (Qiagen Inc., Valencia, CA) according to the manufacturer's protocol. cDNA was synthesized from $1 \mu \mathrm{g}$ of total RNA using the $\mathrm{RT}^{2}$ first strand kit (SABiosciences, Frederick, MD) according to the manufacturer's procedure. PCR was performed under optimal amplification conditions using an $\mathrm{RT}^{2}$ qPCR master mix (SABiosciences) with an Eppendorf Mastercycler ep realplex 2 (Eppendorf North America, Hauppauge, NY). Eighty-four genes related to the WNT/ $\beta$-catenin pathway were screened and plotted by heat map for assessment against cumulative risk factors (see Supplemental Table S1 at http://ajp.amjpathol.org).

\section{Protein Isolation and Western Blot Analysis}

Cells were washed twice with cold PBS, harvested, and lysed in hypotonic buffer ( $10 \mathrm{mmol} / \mathrm{L} \mathrm{HEPES}, 10 \mathrm{mmol} / \mathrm{L}$ $\mathrm{NaCl}, 0.1 \mathrm{mmol} / \mathrm{L}$ EDTA, $0.1 \mathrm{mmol} / \mathrm{L}$ EGTA, and $1 \mathrm{mmol} / \mathrm{L}$ dithiothreitol) containing protease and phosphatase inhibitor cocktails (Sigma-Aldrich) for 20 minutes on ice. Nuclei were pelleted by centrifugation at 10,000 $\times g$ for 5 minutes, and supernatants were collected as a cytoplasmic fraction. Nuclear pellets were then resuspended in hypertonic buffer (20 mmol/L HEPES, $400 \mathrm{mmol} / \mathrm{L} \mathrm{NaCl}$, $0.1 \mathrm{mmol} / \mathrm{L}$ EDTA, $0.1 \mathrm{mmol} / \mathrm{L}$ EGTA, and $1 \mathrm{mmol} / \mathrm{L}$ dithiothreitol) with protease and phosphatase inhibitor cocktails for 45 minutes on ice. Nuclear protein in the supernatant was collected by centrifugation at $20,000 \times$ $g$ for 10 minutes. Total nuclear protein was isolated from an equal number of cells under identical cell densities and cell conditions for the young and aged groups. Nuclear protein levels of $\beta$-catenin were determined by Western blot analysis using monoclonal antibodies against $\beta$-catenin.

Measurement of other proteins, cardiac ( $\alpha / \beta$ isoform) myosin heavy chain $(\alpha / \beta \mathrm{MHC})$, smooth muscle myosin heavy chain, connexin 43, sarcomeric actinin, actin, MEF2C, and glyceraldehyde-3-phosphate dehydrogenase was performed using whole-cell extracts for Western blot analysis. The protein concentration was determined by the Bradford method (Bio-Rad Laboratories, 
Hercules, CA). Lysates containing $20 \mu \mathrm{g}$ of protein were added to an equal volume of $2 \times$ reducing sample buffer (100 mmol/L Tris-Cl, pH 6.8, 200 mmol/L dithiothreitol, 4\% SDS, $20 \%$ glycerol, and $0.2 \%$ bromophenol blue) and heated at $100^{\circ} \mathrm{C}$ for 3 minutes. The samples were separated by gel electrophoresis and were electrotransferred onto a polyvinylidene difluoride membrane. After the blots were blocked with $5 \%$ nonfat milk in Tris-buffered saline and Tween $20(20 \mathrm{mmol} / \mathrm{L} \mathrm{Tris-} \mathrm{HCl}, \mathrm{pH} 7.6,137$ $\mathrm{mmol} / \mathrm{L} \mathrm{NaCl}, 0.05 \%$ Tween 20 ) at $4^{\circ} \mathrm{C}$ overnight, they were incubated with primary antibody for 1 to 2 hours at room temperature, washed with Tris-buffered saline and Tween 20, and incubated (1 to 2 hours) with appropriate horseradish peroxidase-conjugated secondary antibody. The membranes were washed, visualized, and quantified by densitometry.

\section{Immunocytochemical Analysis}

MSCs were seeded on cover slides and incubated under normoxia $\left(21 \% \mathrm{O}_{2}, 5 \% \mathrm{CO}_{2}\right)$ in the presence of lithium chloride $(20 \mathrm{mmol} / \mathrm{L})$ or under hypoxia $\left(1 \% \mathrm{O}_{2}, 5 \% \mathrm{CO}_{2}\right)$ for 16 hours. The cells were fixed with $2 \%$ paraformaldehyde for 10 minutes and then were incubated with primary Ki-67 or $\beta$-catenin antibody for 1 hour. The cells were washed and then incubated with the appropriate Alexa 565-conjugated secondary antibody for 1 hour and then with DAPI and Alexa 488-conjugated phalloidin for 5 minutes. The slides were sealed with fluorescent mounting medium (Dako, Carpinteria, CA). Images were taken using a Nikon Ti-S fluorescence microscope (Nikon Instruments).

\section{Statistical Analysis}

All the values are expressed as mean \pm SD. To determine which factors affected stem cell function, a $\chi^{2}$ test was used for discrete categorical clinical parameters $(0=$ no or $1=$ yes $)$ and a two-tailed $t$-test was used for variables with continuous values. We performed a oneway analysis of variance if $\geq 3$ values were compared, followed by the Newman-Keuls multiple comparison test. Time-related differences were evaluated using a twoway, time-varying analysis of variance, and if the $F$ ratio was significant $(P<0.05)$, differences were specified by a post hoc multiple range test. Linear correlations were determined using a two-way statistical Spearman test. Differences were considered statistically significant at $P<0.05$.

\section{Results}

\section{Patient Characterization}

Bone marrow samples were collected from 22 patients divided into young (mean $\pm \mathrm{SD}, 56.1 \pm 4.8$ years) and aged (mean $\pm S D, 73.3 \pm 7.1$ years) groups according to grouping criteria and were assessed for cardiovascular risk factors. The mean age and comorbidities of the patients are presented in Table 1. The patient ages were significantly different between the young and aged groups, but there were no differences in other cardiovascular risk factors. Age was determined to be the only risk factor that affected proliferation and differentiation of MSCs (see Supplemental Figure S1 at http://ajp. amjpathol.org).

\section{MSC Proliferation, Differentiation, and Myogenic Commitment Are Impaired with Age}

The cultured MSCs were predominantly positive for CD44, CD73, CD90, and CD105, but almost completely negative for CD34, CD45, and CD133 (see Supplemental Figure S2 at http://ajp.amjpathol.org). Cells from the young and aged groups were compared, but no significant differences in the cell surface markers were found.

Patient MSCs grown in vitro for 21 days showed marked differences in their proliferation potential (Figure 1A). Aged MSCs demonstrated less than half the average growth rate over 21 days of expansion compared with young MSCs. On day 7, cell density was lower in aged MSCs compared with young MSCs (Figure 1B). Because cell density can affect rate of growth (for several reasons), we also demonstrated a diminished proliferative potential of aged MSCs when cell plating density (near confluence) was equal as we identified less positive nuclear staining for the proliferative antigen Ki-67 (Figure 1B). There was a significant negative correlation between patient age and the linear growth rate of MSCs in vitro (Figure 1C).

The number of mononuclear cells bearing hematopoietic surface markers (CD34, CD45, and CD133; data not shown) was not different between the two patient groups. However, to determine the capacity for progenitor outgrowth and differentiation, we cultured the mononuclear cells in three-dimensional methylcellulose media. The numbers of blast-forming erythrocyte, CFU granulocytemacrophage, and CFU granulocyte-erythrocyte-monocyte-macrophage colonies were counted to determine total CFUs. The number of blast-forming erythrocyte, CFU granulocyte-macrophage, and CFU granulocyteerythrocyte-monocyte-macrophage progenitors was significantly lower in aged bone marrow mononuclear cells (Figure 1D). In addition, there was a significant negative correlation between total CFUs and the age of the patients from whom the bone marrow was isolated (Figure 1E).

To assess the myogenic differentiation potential in bone marrow MSCs in vitro, cells were first formed into numerically equal clusters to promote contact. We then treated MSC clusters with 5 -Aza $(10 \mathrm{mmo} / \mathrm{L})$. In addition to the contractile proteins $\alpha / \beta \mathrm{MHC}$, we also evaluated the expression of NKX2.5, MEF2C, smooth muscle heavy chain, connexin 43 , and $\alpha$ sarcomeric actinin as other accepted indicators of myogenic differentiation. ${ }^{13,14}$ Differentiation was observed by the expression of $\alpha / \beta \mathrm{MHC}$, connexin 43 , and the myogenic (or cardiomyogenic) transcription factors NKX2.5 and MEF2C (Figure 1F). 
A

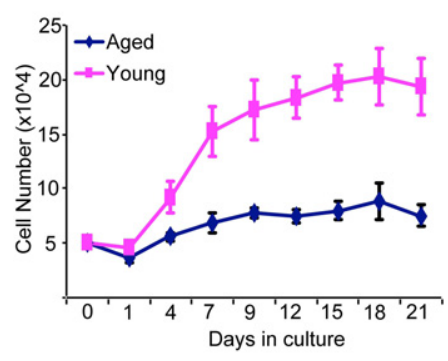

D

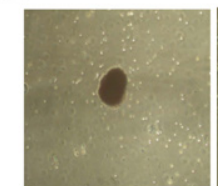

BFU-E

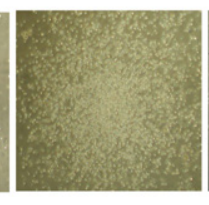

CFU-GM
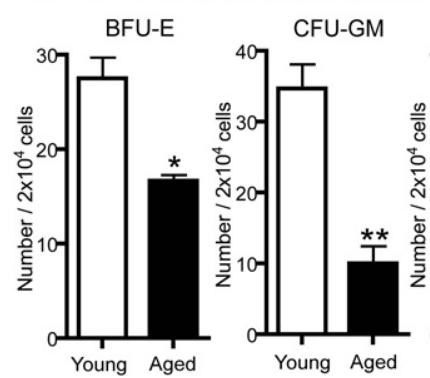

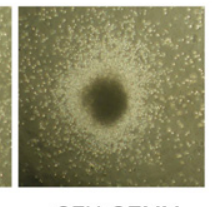

CFU-GEMM
B

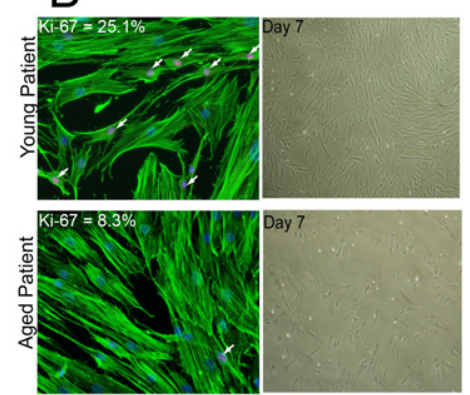

E

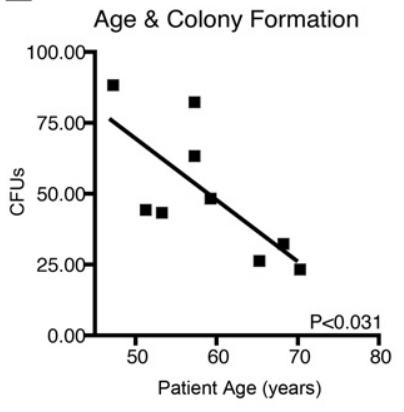

C

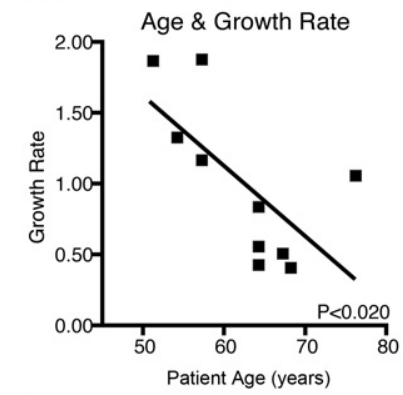

$\mathrm{F}$

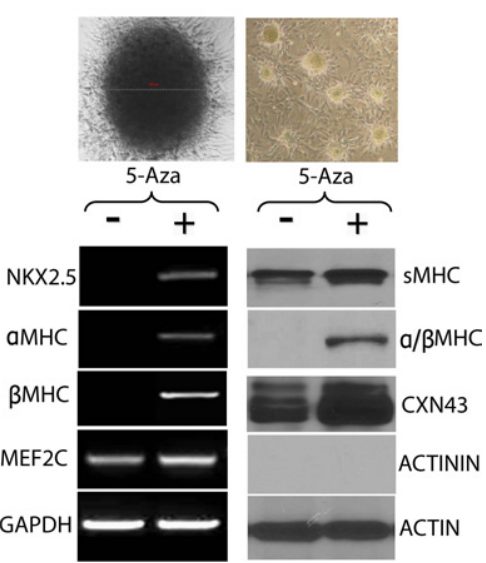

Figure 1. Age-dependent impairment of MSC cell function. A: MSC proliferative growth curves from young and aged patients. Data are given as mean \pm SD. B: MSCs expanding in culture showing nuclear proliferative marker Ki-67 immunocytochemical findings (red; positive cells indicated by arrows), phalloidin-stained F-actin (green), and DAPI-stained nuclei (blue). Phase contrast of MSCs 7 days after isolation from young or aged patients. Original magnification: $\times 20$ (left panels); $\times 10$ (right panels). C: The proliferative growth rate in patient MSCs was significantly negatively correlated with patient age. D: Three-dimensional methylcellulose culture for blast/colony formation of hematopoietic progenitor colonies showed significant reductions in aged patients. Data are given as mean \pm SD. ${ }^{*} P<0.05,{ }^{* * *} P<0.01$. E: The total colony formation rate was significantly negatively correlated with patient age. F: Clustered MSCs were differentiated to a myogenic phenotype with 5-Aza and were characterized by expression of NKX2.5, MEF2C, and $\alpha / \beta$ MHC and increased expression of smooth muscle heavy chain (sMHC) and connexin 43 (CXN43) but no expression of cardiac sarcomeric actinin. GAPDH, glyceraldehyde-3-phosphate dehydrogenase.

\section{Gene Array Identifies an Altered WNT/ $\beta$-Catenin Gene Profile in MSCs}

To determine the mechanism responsible for the diminished proliferation and myogenic differentiation observed in the aged MSCs, we performed real-time PCR array analysis to detect differences in $84 \mathrm{WNT} / \beta$-catenin signaling genes under basal conditions (Figure 2A). The MSCs were first ranked with respect to the cumulative cardiovascular risk factors for the patients (see Supplemental Table S1 at http://ajp.amjpathol.org), and genes from MSCs were plotted in a heat map assessment (Figure 2B). We identified 34 potential genes altered in the MSCs that may be associated with cardiovascular comorbidities. We also compared the relative fold difference in suspect genes from the MSCs isolated from patients with the five highest cardiac risk scores against three patients with the lowest risk scores to provide a numeric representation of the data (Figure $2 \mathrm{C}$ ).

We next performed quantitative correlational analysis by examining the suspect genes identified in the array to identify those specifically correlated with age (Figure 3). We found that MSCs isolated from aged patients demonstrated a gene expression profile that was likely to reduce activity in the WNT/ $\beta$-catenin signaling network. Most no- tably, two extrinsic factors (WNT3A and SFRP4), three membrane factors (FZD6, FZD8, and $L R P 6$ ), and three transcriptional factors (CTNNB1, LEF1, and FOSL) had gene expression levels that were significantly correlated with aged MSCs (Figure 3). The gene CTNNB1 ( $\beta$ catenin) is a component of the TCF/LEF transcriptional complex that regulates canonical WNT signaling at the level of the nucleus. A significant negative correlation was found between MSC age and each of CTNNB1 and its cofactor LEF1 (Figure 3, A and B). Two frizzled receptors, FZD8 and FZD6, have opposing functions in activating $\beta$-catenin. FZD8 activity, which is reported to increase $\beta$-catenin activity, ${ }^{15}$ was negatively correlated with MSC age, whereas FZD6, which is reported to reduce $\beta$-catenin activity, ${ }^{16}$ was positively correlated with MSC age (Figure 3, C and D). WNT3A is reported to bind LRP6/FZD8, ${ }^{17}$ an essential component for stem cell selfrenewal, ${ }^{18}$ and was negatively correlated with MSC age (Figure 3E). LRP6 is a coreceptor for both FZD receptors and was positively correlated with MSC age (Figure 3F). Also, age was negatively correlated with secreted frizzled related protein 4 (SFRP4), a soluble FZD receptor recently implicated in proliferation, differentiation, angiogenesis, and postinfarct repair. ${ }^{19}$ Age was positively correlated with FOS-like antigen 1 (FOSL1), a negative 
A

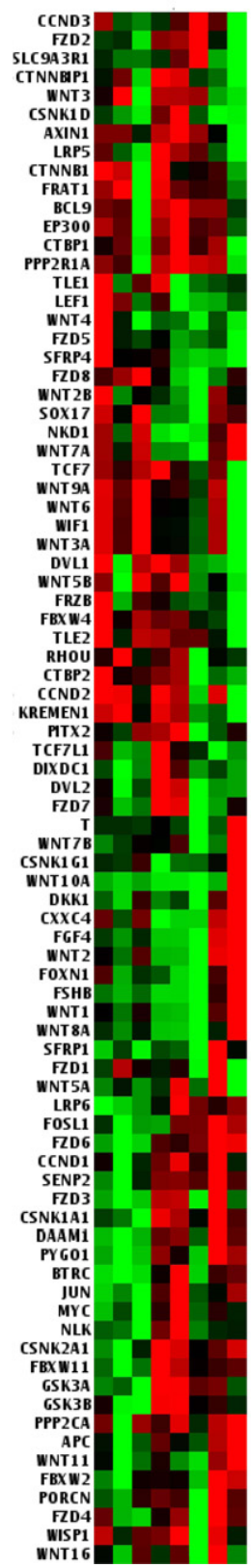

B

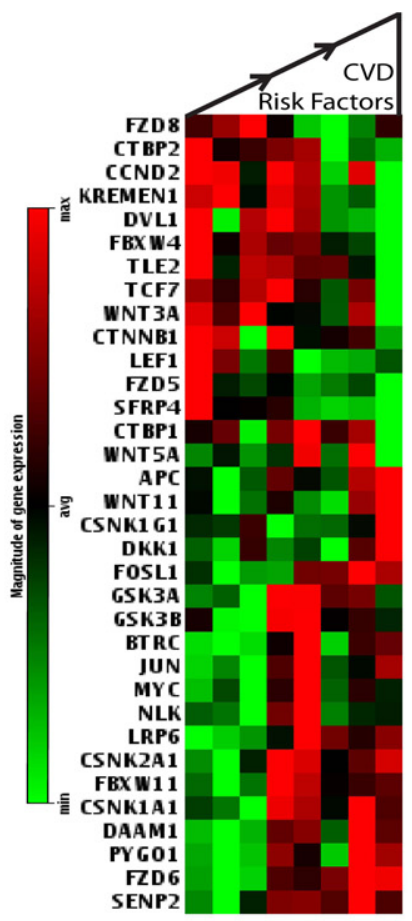

C

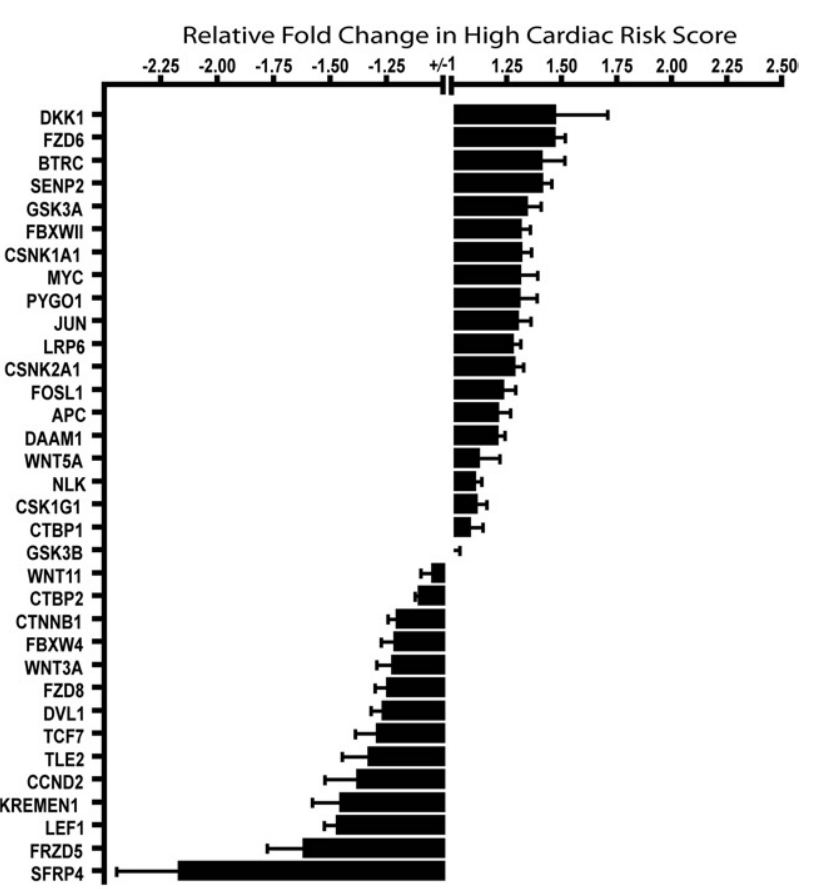

Figure 2. Quantitative gene array identifying WNT/ $\beta$-catenin genes associated with cardiovascular disease (CVD) risk factors. A: Heat map of all 84 genes analyzed by qPCR grouped by gene expression levels. B: Heat map of genes that are differentially expressed relative to the patient CVD risk factors. C: The relative fold change in gene expression in patients at high risk for CVD compared with patients at low risk for CVD. Data are given as mean \pm SD.

regulator of $\beta$-catenin that plays an important role in limiting cell proliferation and differentiation (Figure $3 \mathrm{H}$ ). Taken together, these results implicate a negative association between MSCs from aged cardiac patients and WNT/ $\beta$-catenin signaling.

\section{MSC Nuclear Trafficking of $\beta$-Catenin Protein Is Impaired with Age}

To address, at the protein level, whether $\beta$-catenin nuclear translocation and activity were impaired in MSCs from aged patients, we identified the protein trafficking response after physiologic or pharmacologic stimulation (Figure 4). We first treated the aged MSCs with lithium chloride $(20 \mathrm{mmol} / \mathrm{L})$ to inhibit glycogen synthase kinase
$3 \beta$-dependent $\beta$-catenin degradation. Treatment with lithium resulted in cytoplasmic accumulation and nuclear translocation of $\beta$-catenin. Nuclear translocation was greatest 16 hours after treatment with lithium chloride (Figure 4A). We also determined a physiologic response of $\beta$-catenin by culturing aged MSCs in hypoxia (1\% oxygen) for 16 hours. Total nuclear proteins were probed with phosphorylation-specific antibodies that recognize active $\beta$-catenin (Ser552/675). We found that more active $\beta$-catenin accumulated in the nucleus of young MSCs compared with aged MSCs (Figure 4B). In addition, the accumulation of $\beta$-catenin in response to hypoxia was significantly negatively correlated with age (Figure 4C). Nuclear transactivation of $\beta$-catenin was impaired in MSCs from aged cardiac patients. 
A

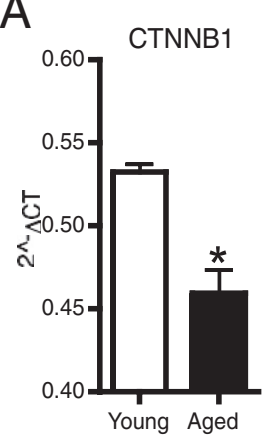

C

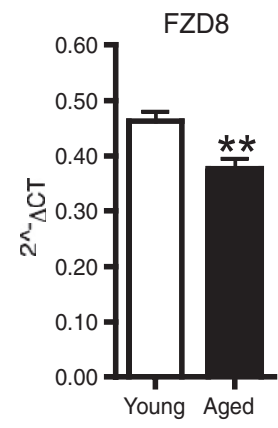

$E$

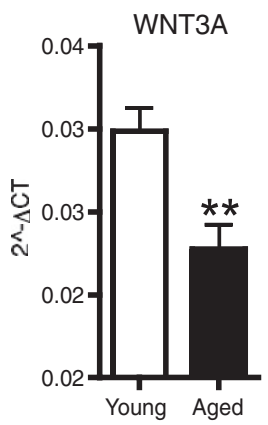

G

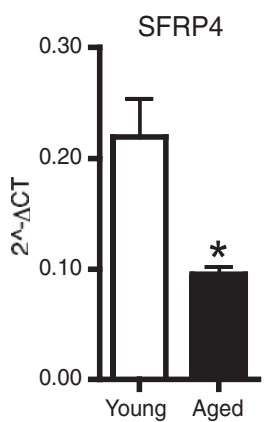

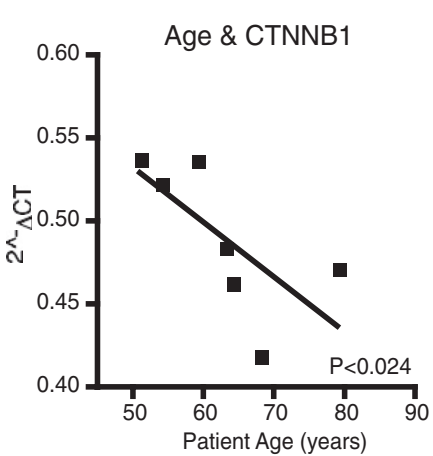
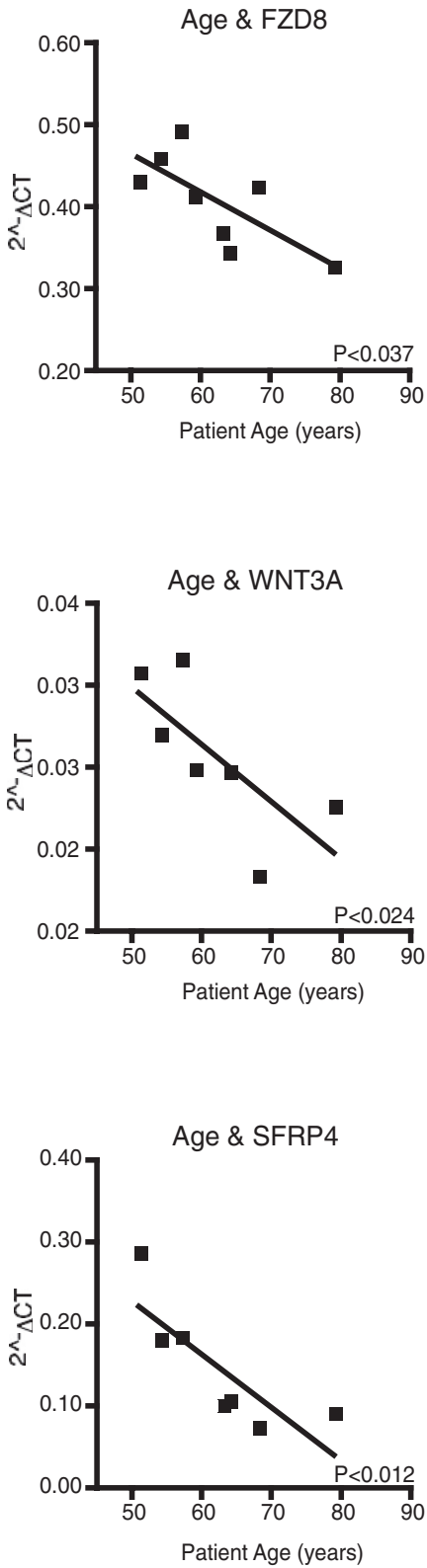

B
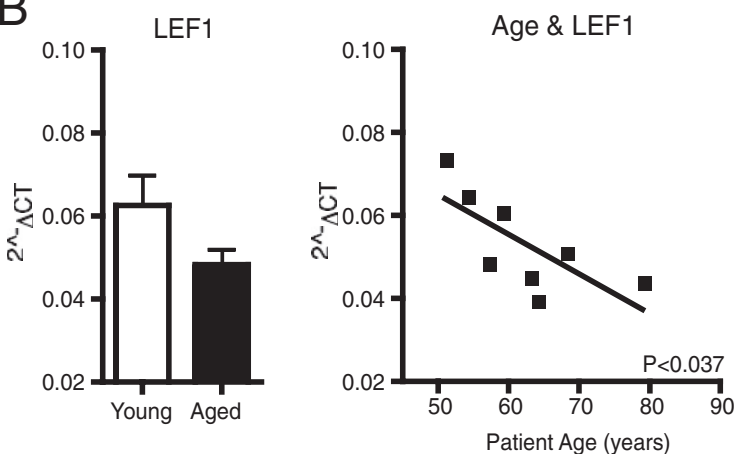

$\mathrm{D}$
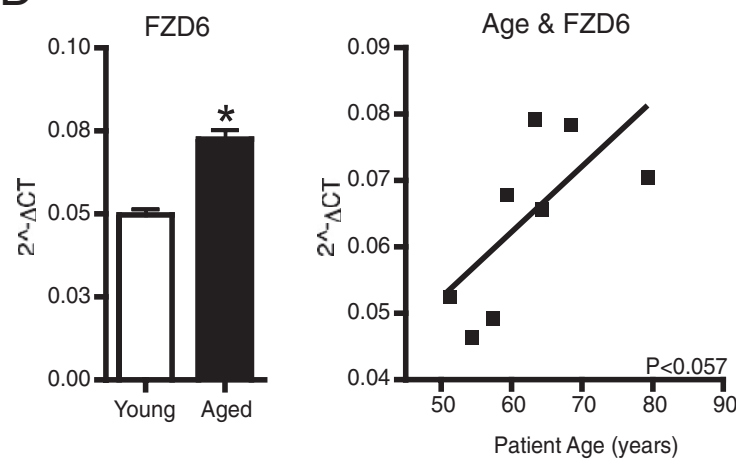

F
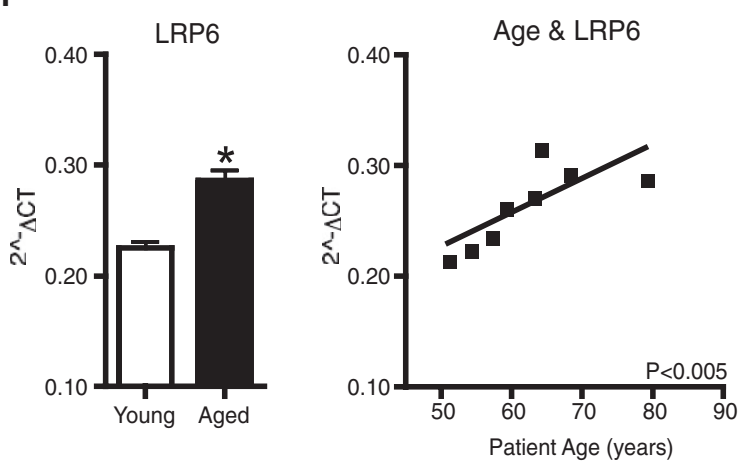

$\mathrm{H}$
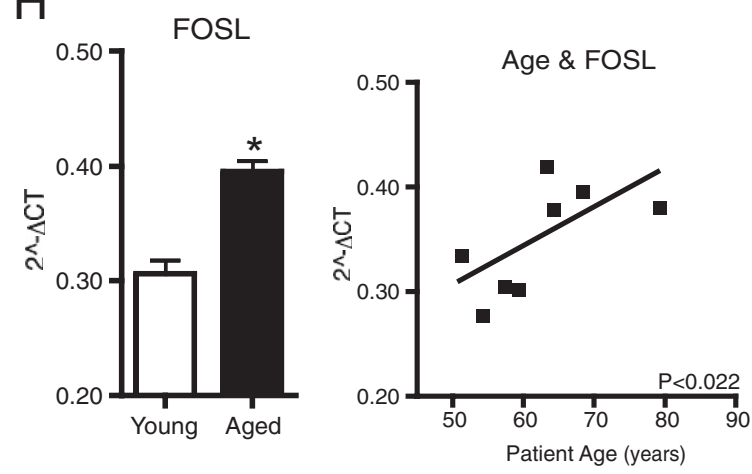

Figure 3. qPCR correlation of WNT/ $\beta$-catenin genes and patient age. Mean \pm SD mRNA expression levels of WNT/ $\beta$-catenin genes in MSCs from young and aged patients (left panels) and correlation of mRNA expression with patient age (right panels). A: CTNNB1 ( $\beta$-catenin). B: LEF1 (lymphoid enhancer-binding factor 1). C: FZD8 (frizzled homolog 8). D: FZD6 (frizzled homolog 6). E: WNT3A (wingless-type MMTV integration site family, member 3 A). F: LRP6 (low-density lipoprotein receptor-related protein 6). G: SFRP4. H: FOSL. ${ }^{*} P<0.01,{ }^{* * *} P<0.05$. 

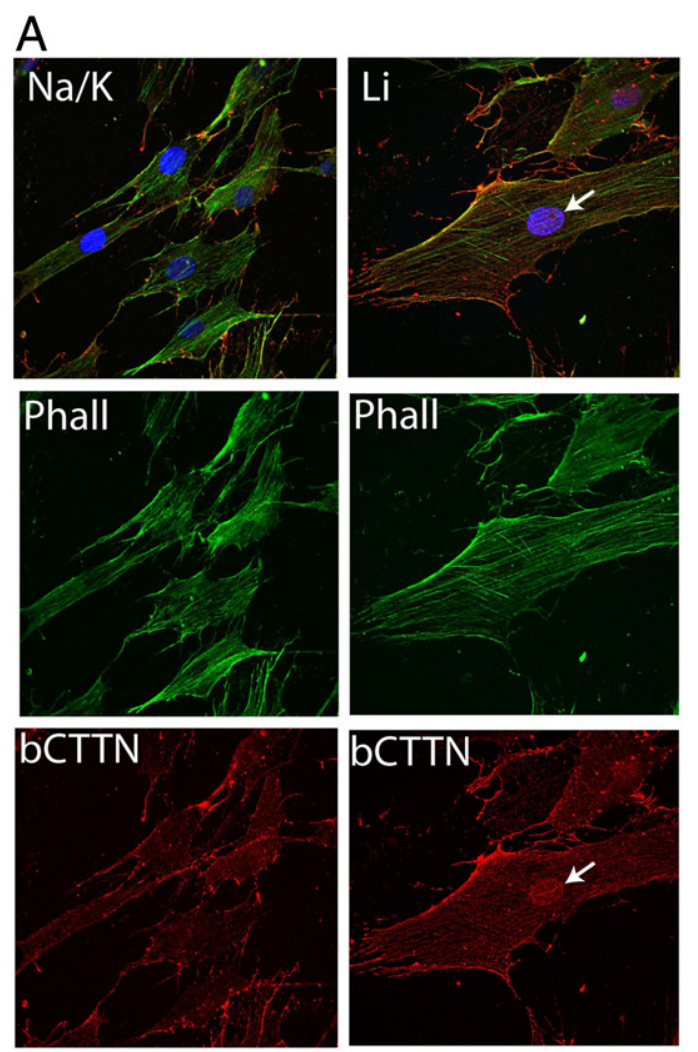

B

Nuclear $\beta$-Catenin

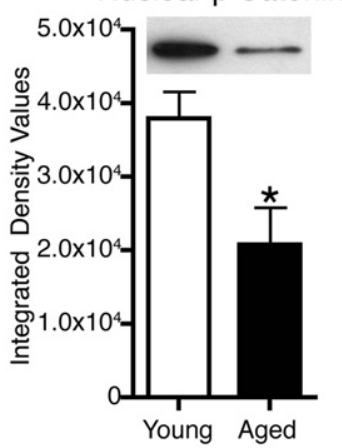

Figure 4. Nuclear accumulation of $\beta$-catenin with lithium and hypoxia treatment of MSCs. A: Immunocytochemical analysis of aged MSCs after 16 hours of stimulation with lithium chloride $(20 \mathrm{mmol} / \mathrm{L}$; right panels $)$ or molar equivalent concentrations of sodium chloride $(10 \mathrm{mmol} / \mathrm{L})$ and potassium chloride $(10 \mathrm{mmol} / \mathrm{L})$ (left panels) as control, demonstrating nuclear $\beta$-catenin accumulation (red; arrows) in the DAPI-stained nucleus (blue) compared with the cytoplasmic distribution of F-actin (green).Original magnification, $\times 40$. B: Western blot analysis of total nuclear protein isolates after exposure to hypoxia for 16 hours demonstrating physiologic impairment of $\beta$-catenin translocation in MSCs from aged patients compared with younger patients. Isolates were from an equal number of cells. Coomassie Blue staining was used to verify equal loading (data not shown). Data are given as mean $\pm \mathrm{SD} .{ }^{*} P<0.01$. C: Nuclear translocation of $\beta$-catenin protein was significantly negatively correlated with patient age.

To evaluate whether the effect of lithium chloride on MSCs may relate to an alteration of their reactive oxygen species production or their viability, we performed additional experiments. We did not find evidence of a reactive oxygen species imbalance with lithium treatment, as determined by dihydroethidium/CM- $\mathrm{H}_{2}$ DCFDA labeling (see Supplemental Figure S3 at http://ajp.amjpathol.org). Similarly, no difference in cell viability was observed with lithium treatment, as measured by LDH toxicity and a cell density assay (see Supplemental Figure S4 at http://ajp. amjpathol.org).

\section{Differentiation of MSCs to a Myogenic Phenotype Is Recoverable through $\beta$-Catenin}

We used myogenic differentiation as a marker to evaluate MSC function. After treating MSCs with 5-Aza to induce a myogenic phenotype, we studied the expression of $\alpha / \beta \mathrm{MHC}$ as a measure of myogenic commitment. $\alpha / \beta \mathrm{MHC}$ expression was significantly reduced in aged MSCs (Figure 5). To quantify myogenic differentiation, we treated equivalent cell densities with 5-Aza and analyzed the level of $\mathrm{MHC}$ expression by qPCR and Western blot analysis. The $\beta \mathrm{MHC}$ transcript (Figure $5 \mathrm{~A}$ ) and $\alpha / \beta \mathrm{MHC}$ protein expression (Figure $5 \mathrm{~B}$ ) were significantly reduced with age. Aged MSCs demonstrated a profile of impaired signaling in genes that predominantly act through the $\beta$-catenin transcriptional complex (Figures 2 and 3 ). However, when MSCs were treated with lithium chloride, they demonstrated elevated $\beta$-catenin translocation (Figure 4). As such, we treated MSCs with lithium chloride before, during, and after myogenic induction with 5-Aza to increase $\beta$-catenin bioavailability. Treatment with lithium chloride eliminated the age-dependent impairment in myogenic induction of MSCs from aged patients as determined by Western blot analysis (Figure 5C). MSCs from most patients (15 of 17) showed significantly more $\mathrm{MHC}$ expression with lithium chloride treatment (Figure 5D). We elected to remove the two patients from this analysis who were nonconforming and identified one as young and one as aged, but both were clinically underweight, suggesting potential metabolic influences on stem cell function. However, to confirm that $\beta$-catenin bioavailability was indeed mechanistically involved in myogenic differentiation, we used small-interfering RNA (siRNA) transfection to specifically knock down $\beta$-catenin before treating cells with lithium chloride (Figure 5E). Activation of $\beta$-catenin by lithium chloride restored the myogenic differentiation capacity of MSCs from aged cardiac patients. Yet, the recovery of myogenic differentiation by lithium was lost in the absence of $\beta$-catenin as a result of siRNA knockdown.

To further characterize the molecular mechanisms that could influence the myogenic differentiation of the MSCs, we screened several senescence and differentiation genes by PCR (see Supplemental Figure S5 at http:// ajp.amjpathol.org) and identified a convergent effect between $\beta$-catenin and MEF2C (Figure 6). Knockdown of $\beta$-catenin using SiRNA resulted in a commensurate reduction in MEF2C mRNA (Figure 6A). Increasing $\beta$-catenin using lithium chloride resulted in a reciprocal elevation in MEF2C protein, whereas knockdown of 


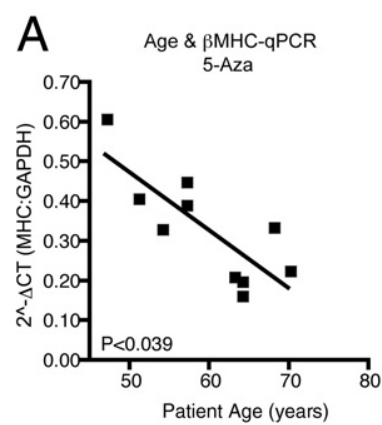

D
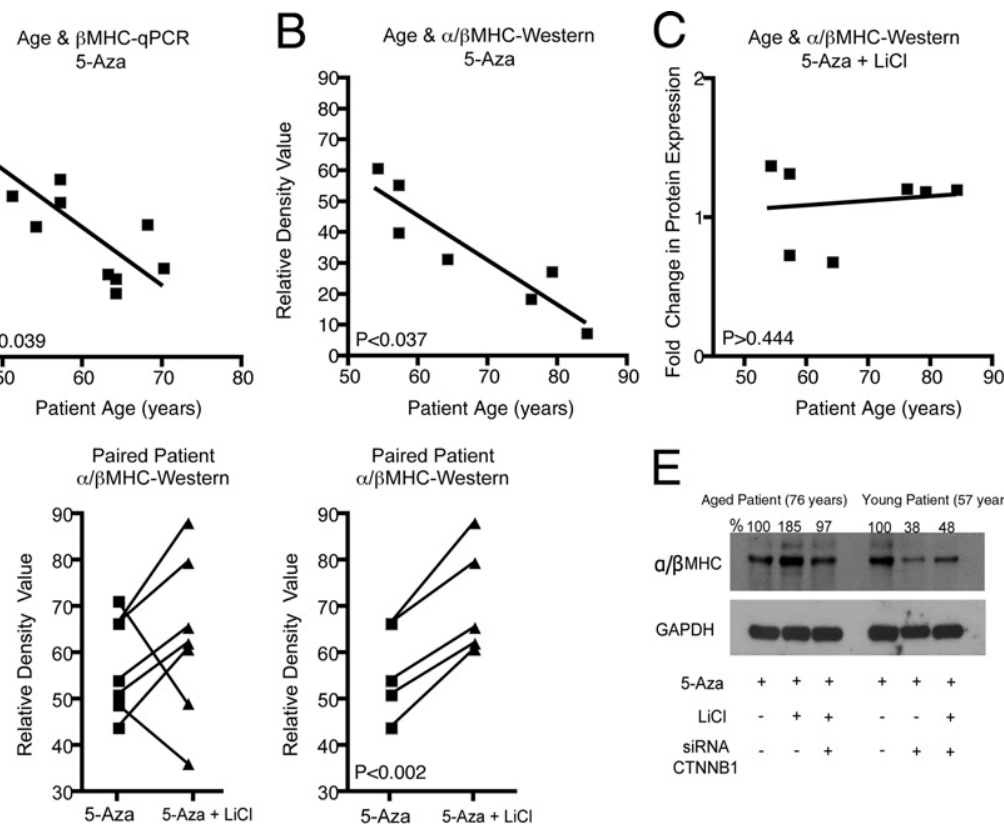

Figure 5. Age-dependent impairment of MSC myogenic commitment and recovery with lithium treatment. $\alpha / \beta \mathrm{MHC}$ (an index of myogenic commitment) after induction with 5-Aza was significantly negatively correlated with patient age as determined by qPCR (A) and Western blot analysis (B). C: After Western blot analysis, the agedependent impairment of myogenic commitment was abrogated in the presence of lithium chloride (LiCl). D: Paired observations of patients treated with lithium during myogenic differentiation show that most patients (left panel) improved their capacity for myogenic induction. Two patients (one young and one aged) showed worse capacity for myogenic induction and were excluded from statistical analysis (right panel). The excluded patients had one common clinical characteristic: underweight. E: Myogenic recovery by lithium therapy is lost in the absence of $\beta$-catenin using siRNA knockdown. GAPDH, glyceraldehyde-3-phosphate dehydrogenase. $\beta$-catenin using SiRNA reduced the level of MEF2C protein (Figure 6B). We performed a predictive analysis of protein interaction using a public software program, GeneMANIA, and identified a highly predictable common protein-to-protein association between $\beta$-catenin and MEF2C, separated by 1-df interactions with HDAC7, NCOA2, TCF7L2, and CARM1 (Figure 6C). These data suggest for the first time that the transcriptional cofactor $\beta$-catenin is convergent with the MEF2C transcription factor in human MSCs.

\section{Discussion}

This study demonstrated that the age of cardiovascular patients was negatively correlated with their bone marrow stem cell proliferation and differentiation in vitro. Ultimately, the recovery of stem cell function requires identification of the molecular mechanisms responsible for the stem cell dysfunction in aged patients. We identified the WNT/ $\beta$-catenin network as a potential target for rejuve- nation of MSCs and demonstrated for the first time a capacity to recover myogenic differentiation by increasing $\beta$-catenin bioavailability.

Proliferative senescence is generally attributed to erosion of telomere complexes in chromosomes during cell division. However, stem cells maintain a level of telomerase, which, together with telomerase reverse transcriptase, is responsible for maintaining telomere extension. Recent studies in follicular/epidermal stem cells demonstrated interdependence between telomerase reverse transcriptase and $\beta$-catenin. ${ }^{20,21}$ This relation could provide a novel avenue for future experiments as these results show low bioavailability of $\beta$-catenin in aged patients. Also, the burden of oxidative stress may contribute to senescence ${ }^{22}$ or stem cell dysfunction. ${ }^{23}$ Oxidative stress diverts $\beta$-catenin from TCF/LEF transcriptional pathways to FOXO transcriptional pathways. ${ }^{24}$ As such, it is not surprising that higher FOXO to TCF/LEF transactivation was associated with increasing age in mice, ${ }^{24}$ a mechanism known to impair stem cell proliferation and

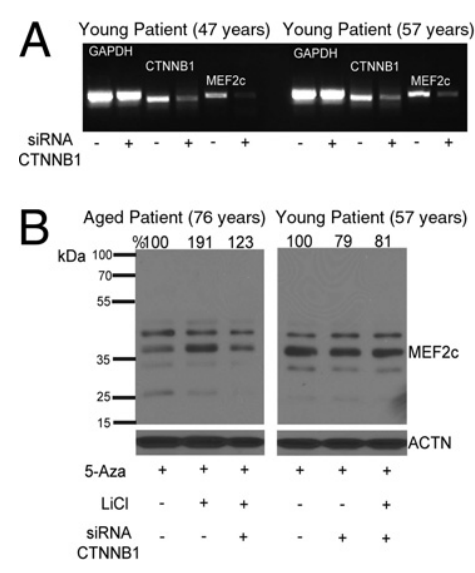

C

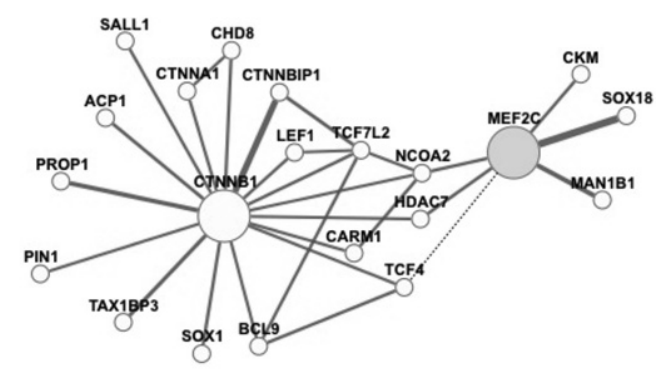

Figure 6. Convergence of $\beta$-catenin and MEF2C in myogenic differentiation. A: Knockdown of $\beta$-catenin using siRNA revealed a concomitant reduction in MEF2C transcript. B: Western blot analysis of MEF2C after myogenic induction shows protein levels in conjunction with $\beta$-catenin bioavailability. C: Predictive interactions using informatics shows a high-probability interactive map with $1^{\circ}$ separation between CTNNB1 ( $\beta$-catenin) and MEF2C, through HDAC7, NCOA2, TCF7L2, and CARM1. Solid gray lines indicate direct physical interactions; dotted line, co-localization. GAPDH, glyceraldehyde-3-phosphate dehydrogenase; $\mathrm{LiCl}$, lithium chloride. 
myogenic differentiation. ${ }^{25}$ Although we found no evidence of excessive reactive oxygen species production or a difference in the response to acute stress (treatment with hydrogen peroxide), we cannot rule out the potential of chronic oxidative stress, which could affect cell function and differentiation. ${ }^{26}$

Previous studies have shown that WNT5A/WNT11 can stimulate myogenic protein expression in human endothelial progenitors ${ }^{27}$ or rat mesenchymal stromal cells, ${ }^{28}$ although the effects of $\beta$-catenin were not addressed. This study also showed some variation in WNT5A and WNT11 gene expression, but neither was significantly correlated with patient age. We identified other factors of WNT signaling upstream of $\beta$-catenin that were correlated with age, such as WNT3A. In young rat bone marrow stromal cells, WNT3A has previously been shown to promote proliferation and myogenic differentiation, which is in line with the present findings. ${ }^{29}$ In addition, reduced WNT3 activity or DKK1 can disinhibit glycogen synthase kinase $3 \beta$ repression of $\beta$-catenin and contribute to an aging phenotype ${ }^{30}$; however, reducing WNT2 increases glycogen synthase kinase $3 \beta$ repression of $\beta$-catenin and induces premature senescence. ${ }^{11}$ These findings are contradictory, and the upstream regulation of $\beta$-catenin remains to be adequately defined in different contexts.

In bone marrow stem cells, the role of $\beta$-catenin has not been firmly established. It was previously proposed that $\beta$-catenin could increase hematopoietic self-renewal, ${ }^{31}$ yet inactivation of $\beta$-catenin did not affect hematopoiesis. $^{32}$ In developing embryos, a consensus has emerged for a biphasic role of WNT/ $\beta$-catenin in cardiogenesis, a process that requires temporal activation, suppression, and reactivation of specific WNT genes to balance stem cell expansion with cardiac stem cell commitment. In the adult heart, $\beta$-catenin may play a physiologic and a pathologic role. Results of adult cardiac studies have been equivocal. $\beta$-Catenin has been implicated as having beneficial ${ }^{33-35}$ and detrimental cardiac effects, ${ }^{36,37}$ suggesting that $\beta$-catenin is either biphasic $^{38}$ in the adult or may contribute differently in response to various cardiac injuries and stress. ${ }^{33,36}$

Connecting the available evidence in development, adult function, and aging is difficult, and there is little information available regarding WNT/ $\beta$-catenin signaling in adults and even less in aged individuals. This study showed that aged MSCs increased myogenic differentiation when $\beta$-catenin was activated by lithium during myogenic induction. Similarly, in a pluripotent model of cardiac specification, WNT3A was expressed days before cardiogenic transcription factors, whereas during specification, lithium and WNT3A increased $\beta$-catenin translocation and accelerated expression of early cardiac markers and cardiac lineage specification. ${ }^{39}$ In other studies, use of an inhibitor of $\beta$-catenin, such as secreted frizzled related protein 2 (SFRP2), reduced myogenic specification and stem cell proliferation in muscle. ${ }^{40}$ Surprisingly, the present study showed that SFRP4 had a strong negative correlation with MSC age. SFRP1 to SFRP5 are generally considered inhibitors of WNT signaling. However, the relation is context dependent, and SFRPs have been reported to activate, ${ }^{41}$ limit, ${ }^{37,42,43}$ or have no effect on $\beta$-catenin activity. ${ }^{44}$ This variation feeds current speculation regarding these molecules, with little consensus and conflicted conclusions. ${ }^{25,35}$ However, a previous examination of stromal sarcoma established an inverse relationship between SFRP4 and $\beta$-catenin expression in undifferentiated cells, which is in agreement with the present findings. ${ }^{42}$ However, reduced myocardial injury and functional recovery after infarction were shown with elevated SFRP4 expression. ${ }^{19}$ Yet, others show that this molecule can inhibit angiogenesis, ${ }^{43}$ at least in studies not involving injury. Further work is required to identify the pathophysiologic role of SFRP proteins.

The present findings also identified a previously unrecognized factor related to age, FOSL1, which also has no known role in MSCs. In other cell types, it has been characterized as a contributor to the AP-1 protein dimer complexes that regulate extracellular matrix, proliferation, and cell survival. In epithelial cells, elevated expression of FOSL1 impaired the phase 2 (antioxidant) response to chemical stress and increased transactivation of matrix metalloproteinases. In the presence of oxidative stress, FOSL1 can impair cell cycle entry or contribute to apoptosis. We showed that lithium treatment did not alter oxidative stress (see Supplemental Figures S2 and S3 at http://ajp.amipathol.org) or the matrix metalloproteinase-9 production of MSCs (see Supplemental Figure S6 at http://ajp.amjpathol.org). However, FOSL1 has also been implicated in the maintenance of trophoblast stem cells ${ }^{45}$ and embryonic patterning proteins, such as HOXB4. ${ }^{46}$ These findings suggest that FOSL1 could limit cell function; however, in cancer cells, FOSL1 is up-regulated in concert with $\beta$-catenin and increases cancer cell function. ${ }^{47}$ Future work is, therefore, warranted to explore these molecular mechanisms further, particularly in noncancer cell types.

Finally, these results demonstrate a potential for convergence of $\beta$-catenin and MEF2C expression that has not previously been demonstrated. We found a commensurate increase in MEF2C protein with increased bioavailability of $\beta$-catenin. This convergence to facilitate myogenic differentiation in MSCs is novel. Cadherin and $\beta$-catenin have been previously demonstrated to regulate temporal and spatial differentiation of cardiomyocytes, ${ }^{48}$ yet loss of WNT11 (which increased $\beta$-catenin levels) exerted a negative influence on MEF2C expression in the developing cardiomyocyte. ${ }^{49}$ However, in the progression of heart failure, MEF2C is co-expressed with FZD6, and the present findings showed significant up-regulation of FZD6, which reduces $\beta$-catenin. Further experiments are needed to elucidate these mechanisms and the intermediary players. We identified HDAC7, NCOA2, TCF7L2, and CARM1 as potential intermediaries. HDAC7 binds $\beta$-catenin in the cytoplasm and represses $\beta$-catenin translocation to the nucleus. ${ }^{50}$ NCOA2 is a transcriptional co-activator partnered with $\beta$-catenin during androgen receptor activation, ${ }^{51}$ and NCOA2 is necessary for MEF2C-dependent gene expression during corticosteroid-induced skeletal muscle differentiation. ${ }^{52}$ MEF2C also binds CARM1 cooperatively with NCOA2 to transactivate the creatine kinase promoter. ${ }^{53}$ Further- 
more, CARM1 also interacts with $\beta$-catenin and TCF4. ${ }^{54}$ Future experiments are needed to address the interplay between these molecules in MSCs and aged phenotypes. In addition, we found that the MSCs from certain (underweight) patients responded in opposing ways to similar stimuli, indicating that unidentified factors in addition to age may affect stem cell function.

We identified a correlation between patient age and stem cell function in a group of patients undergoing cardiac surgery. We cannot be certain that the same effects would be seen in patients without cardiac disease. In the future, larger studies will be required to determine the effects of age on stem cell function in patients with and without cardiac disease.

The restoration of stem cell function with lithium via WNT/ $\beta$-catenin mechanisms is similar to the improved stem cell function reported by Behfar et $\mathrm{al}^{6}$ with a recombinant cocktail of factors used to enhance the therapeutic benefits of human MSCs obtained during cardiac surgery. Therefore, understanding the mechanisms of ageinduced stem cell dysfunction may provide new therapies to rejuvenate aged cells. Cellular senescence contributes to the aging phenotype, but stem cells may preserve their telomere length despite aging-induced dysfunction. Further studies are required to determine the effects of age on cellular senescence and the effects of $\beta$-catenin.

The fact that age ultimately contributes to the deterioration of stem cell function is intuitive. However, the present findings identified important molecular mechanisms affected by aging. These mechanisms were related to developmental stem cell pathways and, importantly, can be targeted to rejuvenate stem cell function, including myogenic differentiation. Future strategies that redress age-dependent mechanisms could improve the clinical utility of cell therapy protocols.

\section{Acknowledgments}

We thank Susannah Moore, Eva Klys, and Kelly Davis for their dedicated communication and administrative support and Dr. John McDermott (York University, Toronto, $\mathrm{ON}$, Canada) for providing human MEF2C plasmid and the antibody against human MEF2C.

\section{References}

1. Reed MJ, Edelberg JM: Impaired angiogenesis in the aged. Sci Aging Knowledge Environ 2004, pe7

2. Kan CD, Li SH, Weisel RD, Zhang S, Li RK: Recipient age determines the cardiac functional improvement achieved by skeletal myoblast transplantation. J Am Coll Cardiol 2007, 50:1086-1092

3. Reffelmann T, Könemann S, Kloner RA: Promise of blood- and bone marrow-derived stem cell transplantation for functional cardiac repair: putting it in perspective with existing therapy. J Am Coll Cardiol 2009, 53:305-308

4. Shih H, Lee B, Lee RJ, Boyle AJ: The aging heart and post-infarction left ventricular remodeling. J Am Coll Cardiol 2011, 57:9-17

5. Fan M, Chen W, Liu W, Du GQ, Jiang SL, Tian WC, Sun L, Li RK, Tian $H$ : The effect of age on the efficacy of human mesenchymal stem cell transplantation after a myocardial infarction. Rejuvenation Res 2010, 13:429-438
6. Behfar A, Yamada S, Crespo-Diaz R, Nesbitt JJ, Rowe LA, PerezTerzic C, Gaussin V, Homsy C, Bartunek J, Terzic A: Guided cardiopoiesis enhances therapeutic benefit of bone marrow human mesenchymal stem cells in chronic myocardial infarction. J Am Coll Cardiol 2010, 56:721-734

7. Cohen ED, Tian Y, Morrisey EE: Wnt signaling: an essential regulator of cardiovascular differentiation, morphogenesis and progenitor selfrenewal. Development 2008, 135:789-798

8. Paige SL, Osugi T, Afanasiev OK, Pabon L, Reinecke H, Murry CE: Endogenous Wnt/ $\beta$-catenin signaling is required for cardiac differentiation in human embryonic stem cells. PLoS One 2010, 5:e11134

9. Bergmann MW: WNT signaling in adult cardiac hypertrophy and remodeling: lessons learned from cardiac development. Circ Res 2010, 107:1198-1208

10. Gessert S, Kühl M: The multiple phases and faces of wnt signaling during cardiac differentiation and development. Circ Res 2010, 107: 186-199

11. Ye X, Zerlanko B, Kennedy A, Banumathy G, Zhang R, Adams PD: Downregulation of Wnt signaling is a trigger for formation of facultative heterochromatin and onset of cell senescence in primary human cells. Mol Cell 2007, 27:183-196

12. Warde-Farley D, Donaldson SL, Comes O, Zuberi K, Badrawi R, Chao P, Franz M, Grouios C, Kazi F, Lopes CT, Maitland A, Mostafavi S, Montojo J, Shao Q, Wright G, Bader GD, Morris Q: The GeneMANIA prediction server: biological network integration for gene prioritization and predicting gene function. Nucleic Acids Res 2010, 38:W214W220

13. Qian Q, Qian H, Zhang X, Zhu W, Yan Y, Ye S, Peng X, Li W, Xu Z, Sun L, Xu W: 5-Azacytidine induces cardiac differentiation of human umbilical cord-derived mesenchymal stem cells by activating extracellular regulated kinase. Stem Cells Dev 2012, 21:67-75

14. van Tuyn J, Knaan-Shanzer S, van DE Watering MJ, DE Graaf M, van der Laarse A, Schalij MJ, van der Wall EE, DE Vries AA, Atsma DE: Activation of cardiac and smooth muscle-specific genes in primary human cells after forced expression of human myocardin. Cardiovasc Res 2005, 67:245-255

15. Nam JS, Turcotte TJ, Smith PF, Choi S, Yoon JK: Mouse cristin/Rspondin family proteins are novel ligands for the Frizzled 8 and LRP6 receptors and activate $\beta$-catenin-dependent gene expression. J Biol Chem 2006, 281:13247-13257

16. Golan T, Yaniv A, Bafico A, Liu G, Gazit A: The human frizzled 6 (HFz6) acts as a negative regulator of the canonical Wnt. $\beta$-catenin signaling cascade. J Biol Chem 2004, 279:14879-14888

17. Komekado H, Yamamoto H, Chiba T, Kikuchi A: Glycosylation and palmitoylation of Wnt-3a are coupled to produce an active form of Wnt-3a. Genes Cells 2007, 12:521-534

18. Luis TC, Weerkamp F, Naber BA, Baert MR, de Haas EF, Nikolic T, Heuvelmans S, De Krijger RR, van Dongen JJ, Staal FJ: Wnt3a deficiency irreversibly impairs hematopoietic stem cell self-renewal and leads to defects in progenitor cell differentiation. Blood 2009, 113:546-554

19. Matsushima K, Suyama T, Takenaka C, Nishishita N, Ikeda K, Ikada Y, Sawa Y, Jakt LM, Mori H, Kawamata S: Secreted frizzled related protein 4 reduces fibrosis scar size and ameliorates cardiac function after ischemic injury. Tissue Eng Part A 2010, 16:3329-3341

20. Choi J, Southworth LK, Sarin KY, Venteicher AS, Ma W, Chang W, Cheung P, Jun S, Artandi MK, Shah N, Kim SK, Artandi SE: TERT promotes epithelial proliferation through transcriptional control of a Myc- and Wnt-related developmental program. PLoS Genet 2008, 4:e10

21. Park JI, Venteicher AS, Hong JY, Choi J, Jun S, Shkreli M, Chang W, Meng Z, Cheung $P, J \mid H$, McLaughlin M, Veenstra TD, Nusse R, McCrea PD, Artandi SE: Telomerase modulates Wnt signalling by association with target gene chromatin. Nature 2009, 460:66-72

22. Richter T, von Zglinicki T: A continuous correlation between oxidative stress and telomere shortening in fibroblasts. Exp Gerontol 2007 42:1039-1042

23. Tothova Z, Kollipara R, Huntly BJ, Lee BH, Castrillon DH, Cullen DE, McDowell EP, Lazo-Kallanian S, Williams IR, Sears C, Armstrong SA, Passeque E, DePinho RA, Gilliland DG: FoxOs are critical mediators of hematopoietic stem cell resistance to physiologic oxidative stress. Cell 2007, 128:325-339

24. Almeida M, Han L, Martin-Millan M, O'Brien CA, Manolagas SC: Oxidative stress antagonizes Wnt signaling in osteoblast precursors 
by diverting $\beta$-catenin from T cell factor- to forkhead box O-mediated transcription. J Biol Chem 2007, 282:27298-27305

25. Deb A, Davis BH, Guo J, Ni A, Huang J, Zhang Z, Mu H, Dzau VJ: SFRP2 regulates cardiomyogenic differentiation by inhibiting a positive transcriptional autofeedback loop of Wnt3a. Stem Cells 2008, 26:35-44

26. Liu J, Cao L, Finkel T: Oxidants, metabolism, and stem cell biology. Free Radic Biol Med 2011, 51:2158-2162

27. Koyanagi M, Haendeler J, Badorff C, Brandes RP, Hoffmann J, Pandur P, Zeiher AM, Kuhl M, Dimmeler S: Non-canonical Wnt signaling enhances differentiation of human circulating progenitor cells to cardiomyogenic cells. J Biol Chem 2005, 280:16838-16842

28. He Z, Li H, Zuo S, Pasha Z, Wang Y, Yang Y, Jiang W, Ashraf M, Xu $M$ : Transduction of Wnt11 promotes mesenchymal stem cell transdifferentiation into cardiac phenotypes. Stem Cells Dev 2011, 20:17711778

29. Shang YC, Wang SH, Xiong F, Zhao CP, Peng FN, Feng SW, Li MS, Li Y, Zhang C: Wnt3a signaling promotes proliferation, myogenic differentiation, and migration of rat bone marrow mesenchymal stem cells. Acta Pharmacol Sin 2007, 28:1761-1774

30. Liu H, Fergusson MM, Castilho RM, Liu J, Cao L, Chen J, Malide D, Rovira II, Schimel D, Kuo CJ, Gutkind JS, Hwang PM, Finkel T: Augmented Wnt signaling in a mammalian model of accelerated aging. Science 2007, 317:803-806

31. Reya T, Duncan AW, Ailles L, Domen J, Scherer DC, Willert K, Hintz L, Nusse R, Weissman IL: A role for Wnt signalling in self-renewal of haematopoietic stem cells. Nature 2003, 423:409-414

32. Cobas M, Wilson A, Ernst B, Mancini SJ, MacDonald HR, Kemler R, Radtke $\mathrm{F}: \beta$-Catenin is dispensable for hematopoiesis and lymphopoiesis. J Exp Med 2004, 199:221-229

33. Hahn JY, Cho HJ, Bae JW, Yuk HS, Kim KI, Park KW, Koo BK, Chae $I H$, Shin CS, Oh BH, Choi YS, Park YB, Kim HS: $\beta$-Catenin overexpression reduces myocardial infarct size through differential effects on cardiomyocytes and cardiac fibroblasts. J Biol Chem 2006, 281: 30979-30989

34. Templin C, Kotlarz D, Faulhaber J, Schnabel S, Grote K, Salguero G, Luchtefeld M, Hiller KH, Jakob P, Naim HY, Schieffer B, HilfikerKleiner D, Landmesser U, Limbourg FP, Drexler H: Ex vivo expanded hematopoietic progenitor cells improve cardiac function after myocardial infarction: role of beta-catenin transduction and cell dose. J Mol Cell Cardiol 2008, 45:394-403

35. Kobayashi K, Luo M, Zhang Y, Wilkes DC, Ge G, Grieskamp T, Yamada C, Liu TC, Huang G, Basson CT, Kispert A, Greenspan DS, Sato TN: Secreted frizzled-related protein 2 is a procollagen $C$ proteinase enhancer with a role in fibrosis associated with myocardial infarction. Nat Cell Biol 2009, 11:46-55

36. Zelarayan LC, Noack C, Sekkali B, Kmecova J, Gehrke C, Renger A, Zafiriou MP, van der Nagel R, Dietz R, de Windt LJ, Balligand JL, Bergmann MW: $\beta$-Catenin downregulation attenuates ischemic cardiac remodeling through enhanced resident precursor cell differentiation. Proc Natl Acad Sci U S A 2008, 105:19762-19767

37. Ouchi N, Higuchi A, Ohashi K, Oshima Y, Gokce N, Shibata R, Akasaki Y, Shimono A, Walsh K: Sfrp5 is an anti-inflammatory adipokine that modulates metabolic dysfunction in obesity. Science 2010, 329:454-457

38. He W, Zhang L, Ni A, Zhang Z, Mirotsou M, Mao L, Pratt RE, Dzau VJ: Exogenously administered secreted frizzled related protein 2 (Sfrp2) reduces fibrosis and improves cardiac function in a rat model of myocardial infarction. Proc Natl Acad Sci U S A 2010, 107:2111021115
39. Nakamura T, Sano M, Songyang Z, Schneider MD: A Wnt- and $\beta$-catenin-dependent pathway for mammalian cardiac myogenesis. Proc Natl Acad Sci U S A 2003, 100:5834-5839

40. Polesskaya A, Seale P, Rudnicki MA: Wnt signaling induces the myogenic specification of resident CD45+ adult stem cells during muscle regeneration. Cell 2003, 113:841-852

41. Dufourcq P, Descamps B, Tojais NF, Leroux L, Oses P, Daret D, Moreau C, Lamaziere JM, Couffinhal T, Duplaa C: Secreted frizzledrelated protein-1 enhances mesenchymal stem cell function in angiogenesis and contributes to neovessel maturation. Stem Cells 2008, 26:2991-3001

42. Hrzenjak A, Tippl M, Kremser ML, Strohmeier B, Guelly C, Neumeister D, Lax S, Moinfar F, Tabrizi AD, Isadi-Moud N, Zatloukal K, Denk H: Inverse correlation of secreted frizzled-related protein 4 and $\beta$-catenin expression in endometrial stromal sarcomas. J Pathol 2004, 204:19-27

43. Muley A, Majumder S, Kolluru GK, Parkinson S, Viola H, Hool L, Arfuso F, Ganss R, Dharmarajan A, Chatterjee S: Secreted frizzled-related protein 4: an angiogenesis inhibitor. Am J Pathol 2010, 176:15051516

44. Chung YS, Baylink DJ, Srivastava AK, Amaar Y, Tapia B, Kasukawa Y, Mohan S: Effects of secreted frizzled-related protein 3 on osteoblasts in vitro. J Bone Miner Res 2004, 19:1395-1402

45. Abell AN, Granger DA, Johnson NL, Vincent-Jordan N, Dibble CF, Johnson GL: Trophoblast stem cell maintenance by fibroblast growth factor 4 requires MEKK4 activation of Jun $\mathrm{N}$-terminal kinase. Mol Cell Biol 2009, 29:2748-2761

46. Krosl J, Sauvageau G: AP-1 complex is effector of Hox-induced cellular proliferation and transformation. Oncogene 2000, 19:51345141

47. Young MR, Colburn NH: Fra-1 a target for cancer prevention or intervention. Gene 2006, 379:1-11

48. Linask KK, Knudsen KA, Gui YH: N-cadherin-catenin interaction: necessary component of cardiac cell compartmentalization during early vertebrate heart development. Dev Biol 1997, 185:148-164

49. Nagy II, Railo A, Rapila R, Hast T, Sormunen R, Tavi P, Räsänen J, Vainio SJ: Wnt-11 signalling controls ventricular myocardium development by patterning $\mathrm{N}$-cadherin and $\beta$-catenin expression. Cardiovasc Res 2010, 85:100-109

50. Margariti A, Zampetaki A, Xiao Q, Zhou B, Karamariti E, Martin D, Yin X, Mayr M, Li H, Zhang Z, De Falco E, Hu Y, Cockerill G, Xu Q, Zeng L: Histone deacetylase 7 controls endothelial cell growth through modulation of beta-catenin. Circ Res 2010, 106:1202-1211

51. Song LN, Gelmann EP: Interaction of $\beta$-catenin and TIF2/GRIP1 in transcriptional activation by the androgen receptor. J Biol Chem 2005, 280:37853-37867

52. Chen SL, Dowhan DH, Hosking BM, Muscat GE: The steroid receptor coactivator, GRIP-1, is necessary for MEF-2C-dependent gene expression and skeletal muscle differentiation. Genes Dev 2000, 14 1209-1228

53. Chen SL, Loffler KA, Chen D, Stallcup MR, Muscat GE: The coactivator-associated arginine methyltransferase is necessary for muscle differentiation: CARM1 coactivates myocyte enhancer factor-2. J Biol Chem 2002, 277:4324-4333

54. Koh SS, Li H, Lee YH, Widelitz RB, Chuong CM, Stallcup MR: Synergistic coactivator function by coactivator-associated arginine methyltransferase (CARM) 1 and $\beta$-catenin with two different classes of DNA-binding transcriptional activators. J Biol Chem 2002, 277 26031-26035 